China Perspectives

$2010 / 3 \mid 2010$

Taiwan: The Consolidation of a Democratic and Distinct Society

\title{
Taiwanese Historiography
}

Towards a "Scholarly Native History"

Damien Morier-Genoud

\section{OpenEdition \\ Journals}

Édition électronique

URL : http://journals.openedition.org/chinaperspectives/5306

DOI : 10.4000/chinaperspectives.5306

ISSN : 1996-4617

Éditeur

Centre d'étude français sur la Chine contemporaine

Édition imprimée

Date de publication : 15 septembre 2010

ISSN : 2070-3449

\section{Référence électronique}

Damien Morier-Genoud, «Taiwanese Historiography », China Perspectives [En ligne], 2010/3 | 2010, mis en ligne le 01 septembre 2013, consulté le 28 octobre 2019. URL : http://journals.openedition.org/ chinaperspectives/5306 ; DOI : 10.4000/chinaperspectives.5306 


\title{
Taiwanese Historiography
}

\author{
Towards a "Scholarly Native History"
}

DAMIEN MORIER-GENOUD

Historical studies of Taiwan have been moulded by schools of thought of diverse origins that support divergent and opposing readings of the island's past. The $1990 \mathrm{~s}$ and the $2000 \mathrm{~s}$ have seen the emergence of a new scientific history of Taiwan, freed from the patterns of nationalist Chinese historiography. This article focuses on the conditions of elaboration and modalities of writing of this history. It examines in more detail the critical thought and recent work of two Taiwanese historians who seek to grasp, beyond the rigid divisions of political periodisation, certain dynamics of Taiwanese history and invite us to rethink the long-term transition of the island's society towards the modern era.

L ike the history it examines, Taiwanese historiography proceeds from junctions and linearities introduced by the political, ideological, and scientific circumstances of the moment. As suggested by the historian Chang Lung-chih, historical studies of Taiwan are not marked so much by a succession of mutually exclusive paradigms and interpretative frameworks as by phenomena of negotiation, competition, and superposition of rich and multiple traditions of knowledge. ${ }^{(1)}$ In this article, we will first look at some of these polymorphous currents and seek to highlight the various readings of the history of Taiwan that they carry or support. We will then refer to the critical thinking recently undertaken by Chang Lung-chih on the conditions of modelisation of a historiography anchored in the context native to Taiwan, possessing its own analytical models that make it possible to grasp as closely as possible the tangle of continuities and upheavals in the process of the island's history. ${ }^{(2)}$ Finally, we will see to what extent Ka Chihming's work on the island's landholding system before and after Japanese colonisation is amenable to the critical examination of Chang Lung-chih, how it corresponds to the theoretical criteria of what Chang calls a "scholarly native history" (bentu xueshushi), and whether it is able to shed light on the gradual entry of island society into the modern era.

\section{The diversity of historiographical traditions in Taiwan}

The arrival in Taiwan of scientific history as a modern academic discipline dates back to the Japanese colonisation, when the colonial authorities in 1928 established the first history course at the Imperial University of Taihoku (Tai- hoku teikoku daigaku), the forerunner of Taiwan's National University. Despite the professionalisation of studies of Taiwanese society begun at this period, these remained a mere underlying academic stream linked to the "new (Japanese) national studies" (shinkokugaku). To the Japanese, the formation and expansion of their empire in Asia necessitated familiarity with Taiwan, the acquisition of which was an essential step in the "Imperial March to the South" (teikoku nanshin). As a testing-ground for Japanese colonial expansion, the island was supposed to allow the occupiers to increase, by extension, their knowledge of the societies of South China and Southeast Asia to which they planned to extend their domination. The historical studies initiated by the colonizer in Taiwan at that time bore the stamp of the positivist approach of nineteenth century German historiography embodied by Leopold von Ranke (1795-1886).

Ranke's influence in the Japanese archipelago dates back to the Meiji Restoration of 1868, when the historian Shigeno Yasutsugu (1827-1910), seeking to establish Japanese history as an academic discipline, brought to the new history department of the Imperial University of Tokyo Ludwig Riess (1861-1928), who had trained with Ranke at the University of Berlin from 1880 to 1885 .

1. Chang Lung-chih, "Re-imagining Community from Different Shores: Nationalism, Post-colonialism and Colonial Modernity in Taiwanese Historiography," in Steffi Richter (ed.), Contested Views of a Common Past: Revisions of History in Contemporary East Asia, Frankfurt, Campus, 2008, pp. 139-155, and p. 142.

2. Chang Lung-chih, "Zhimin xiandaixing fenxi yu Taiwan jindaishi yanjiu. Bentu shixue shi yu fangfalun chuyi" (An analysis of colonial modernity and studies of Taiwan's modern history: Some personal remarks on the history of native historiography and its methodology), in Wakabayashi Masahiro, Wu Mi-cha (ed.), Kuajie de Taiwanshi yanjiu: Yu Dongyashi de jiaocuo (Transcending the Boundary of Taiwanese History: Dialogue with East Asian History), Taipei, Bozhongzhe wenhua, 2004, pp. 133-160. 
The guest professor introduced the new methods and approaches of European historiography, initiating the younger generation of the Tokyo School to his master's theses, which reduced historical exegesis to a scientific critique of facts and primary sources. ${ }^{(3)}$ Later, in the Japanese colony of Taiwan, several Japanese professors, such as Fujita Toyohashi (18691929), Ichimura Sanjirō (1864-1947), Iwao Seiichi (19001988), and Murakami Naojirō (1868-1966), supervised training in history at the University of Taihoku, where they in turn introduced Ranke's theses and methods. Thus, contact with Japanese historians and reading the work, then in vogue in Japan, of Fukuzawa Yukichi (1835-1901), Naka Michiyo (1851-1908), and Kuwabara Jitsuzō (1870-1931), enabled members of the Taiwanese elite of the 1920s and 1930s, who had managed to attend the university of Taihoku or had been able to study directly in the Japanese capital, to familiarise themselves with modern German historiography. ${ }^{(4)}$

The arrival of the Kuomintang in Taiwan in 1945, followed by the establishment in Taipei of the Academia Sinica, refounded on 1 November 1949 and directly attached to the Presidency of the Republic of China, marked both a break in content and a continuity in the evolution of island historiography. In terms of content, the "national history" (guoshi) taught on the island was no longer that of the Japanese Empire but of the Chinese Dynasties and the Republic of China. The continuity was in the form of historical work undertaken in the academy that continued, as during the Japanese period, to defer to the positivist inheritance of Ranke. Fu Ssu-nien (1896-1950), founding father of the Academica Sinica's Institute of History and Philology and of the Chinese school of "historical documentation" (shiliao xuepai), had in fact lived in Germany in the 1920s, and was also influenced by Ranke's theses. While he died within a year of arriving in Taiwan, his influence in the academy remained very significant up to the 1960s, thanks to his former fellow students and to his master Hu Shih (1891-1962), who continued to keep his teaching alive. ${ }^{(5)}$

In his lifetime, Fu Ssu-nien sought to reconnect with the kaozhengxue, the tradition known as the "verification of evidence," which dominated the eighteenth century in China, ${ }^{(6)}$ and the highly critical spirit of which Fu regarded as compatible with the positivist approach and scientific rigour of German historiography. Drawing on the philological approach of the kaozhengxue and on European historical sciences, Fu Ssu-nien sought to break with all forms of interpretation in history, which he dismissed as based on value judgements and a fortiori subjective. The idea behind his thinking was that historical interpretation, being bound to language through its narrative form, cannot escape a "selfemplotment" that leads it away from reality. Only textual and philological criticism, coupled with meticulous archaeological research, allows the historian to arrive at the veracity of the facts. This obstinate quest for objectivity led $\mathrm{Fu} \mathrm{Ssu-}$ nien and the shiliao school to radical condemnation of the subject as interfering with reality in an unjustified manner or with the aim of obtaining some benefit, particularly political. Such a position not only challenged the a priori conceptions of Marxist historical determinism and historical materialism, but also rejects the introspective and moral dimension of Song Neo-Confucianism, which moulded Chinese history from the thirteenth century. ${ }^{(7)}$

In the mid-1960s, the arrival in the scientific community of a new generation of researchers, most of them trained in the United States and brought together by the journals Thought and Language (Si yu yan) and Economics and Society (Shihuo yuekan), led to the decline of the shiliao school. This coincided with a change of direction in methodology and a return to favour of the knowing subject in historical studies in Taiwan. Historians in the Academy now called for the introduction of new methods and approaches borrowed from the Western social sciences, and advocated interdisciplinarity in their work. ${ }^{(8)}$ Thus it was mainly through American mediation that the major theories of Western social sciences were introduced into Taiwan up to the 1970s, ${ }^{(9)}$ and these contributed to a transcending of shiliao erudition and to a modelisation of historiographical observation. Functionalism, as illustrated in the theory of Talcott Parsons-which

3. Concerning European influences on Japanese historiography in the Meiji era, cf. John S Brownlee, Japanese Historians and the National Myths, 1600-1945: The Age of the Gods and Emperor Jinmu, UBC Press/University of Tokyo Press, 1997, pp. 71-80.

4. For a brief survey of the history course at the Imperial University of Taipei and an introduction to its members (both staff and students), cf. Chen Wei-chih, "Wenzhengbu shixueke jianjie" (A brief introduction to the history courses in the department of human and political sciences), Academia: Taibei diguo daxue yanjiu tongxun (Academia: Research bulletin on the imperial university of Taihoku), 1, 1996, pp. 72-98.

5. On the life and work of Fu Ssu-nien, cf. Wang Fan-sen, Fu Ssu-nien: A Life in Chinese History and Politics, Cambridge University Press, 2000.

6. On the kaozheng school, cf. Benjamin Elman, From Philosophy to Philology: Intellectual and Social Aspects of Change in Late Imperial China, Los Angeles, University of California, 2001, particularly pp. 71-122.

7. Wang Fan-sen, Fu Ssu-nien: A Life in Chinese History and Politics, op. cit., pp. 126-139.

8. Wang Qingjia (Edward Q. Wang), Taiwan shixue wushi nian (1950-2000): Chuancheng, fangfa, quxiang (Fifty years of Taiwanese historiography: Legacies, methods and orientations), Taipei, Maitian chubanshe, 2002, pp. 43-97.

9. In the context of the Cold War, American contributions to the island, both financial and intellectual, were considerable. Many scientific projects were carried out thanks to American subsidies. Cf. Chang Peng-yuan, Guo Tingyi, Fei Zhengqing, Wei Muting: Taiwan yu Meiguo xueshu jiaoliu ge'an chutan (Kuo Ting-yee, John K. Fairbank and Clarence M. Wilbur: Preliminary enquiry into scientific exchanges between Taiwan and the United States), Taipei, Institute of Modern History, Academia Sinica, 1997. 
themselves drew on Weber's thought-served as a model for Taiwanese sociologists such as Ye Chi-cheng in rethinking the elements of the structuralisation of social action and their modalities. It made possible a systematic approach to identifying the structural variables and dynamics of interconnection between institutions, individuals, groups, and their cultures. ${ }^{(10)}$ Weberian sociology, which interested Ambrose King, who lived in Taiwan until 1967, allowed new thinking on the modernisation of the Chinese world and on practical incentives to action dictated by religion and the ethos that flowed from it. ${ }^{\text {(II) }}$ Culturalism and behaviourism, in the light of the categories of "culture" and "personality," allowed Yang Kuo-shu and Li Yih-yuan to re-examine questions of "national character" (guojia xingge) and "social behaviour" (shehui xingwei). ${ }^{(12)}$ Intellectual history was also re-evaluated under the influence of the Chinese American historian Yu Ying-shih, who made known on the island the liberal trend in historiography represented by Isaiah Berlin and Robin Collingwood. (13) Through publications in English, young Taiwanese historians also familiarised themselves with the French Annales school, whose methods they sought to apply in order to grasp economic practices and social phenomena over the longue durée. ${ }^{(14)}$

It must be recognised, however, that until the mid-1970s, historiographical debate in Taiwan was restricted to questions of methodology, without being actually applied to the case of Taiwan. The local, even when grasped in its particularities, was systematically connected to a socio-cultural whole that was defined as "Chinese." During the three decades after the arrival of the Kuomintang in Taiwan, historical studies of island society did not have much more chance of emerging than they had enjoyed under the Japanese occupation. ${ }^{(15)}$ After 1945, the policy of sinicisation applied by the Chinese Nationalist Party did not allow a rethinking of the differences in experience between the Taiwanese and the mainlanders. The Kuomintang's project of cultural reconstruction and political subjugation, one the objectives of which was to purge island society of its Japanese influences, formed part of a wider scheme of governance aimed at rebuilding the Chinese nation from Taiwan in accordance with the fiction of the Republic of China, and at transforming the island's inhabitants into authentic Chinese patriots. The $\mathrm{Na}$ tionalist Party's constant efforts to reinforce the ethnic and cultural links between the islanders and the inhabitants of the ancestral Chinese homeland (zuguo) were based on a single linear national narrative that placed Taiwan's past and future destiny on a trajectory congruent with that of the Chinese mainland. The Chinese nationalist fiction of history supported the myth of a "Great China" reified in a primordial past, from which the islanders could not escape. The Kuomintang's policy of domination left no room for a specifically Taiwanese ethnicity and tradition, even on a symbolic level. ${ }^{(16)}$

The first attempts at creating a distance from Chinese nationalist historiography in academic circles date back to the mid-1970s, in a socio-political context marked by the withdrawal of recognition of the Republic of China on the international scene and by the subsequent crisis of legitimacy of the Nationalist Chinese government in Taiwan. This spurred a desire in society to revalue island potential, which in the scientific community translated into renewed interest in local studies as part of a return to favour of a Taiwanese reality eclipsed by official history.

This was the case in the historical anthropology work of Chen Chi-nan, who focused on the evolution of relations between various sub-ethnic groups in Taiwan during the Manchu period (1683-1895). At the time, Chen Chi-nan produced the concept of the "indigenisation" (tuzhuhua) of Taiwanese society in order to analyse the social and cultural evolution of Taiwan in the eighteenth and nineteenth centuries. In contrast with the concept of the "integration of the periphery" (neidihua) put forward at the same time by the Chinese nationalist historian Li Kwo-chi, who emphasised the intensification of the process of sinicisation of Taiwan in the nineteenth century, Chen Chi-nan emphasised the endogenous factors of change specific to island society. His approach and interpretation took the opposite view from that of the official version of history reflected in the theses of Li Kwo-chi by emphasising the points of dis-

10. Ye Chi-cheng, "Sanshi nian lai Taiwan diqu Zhongguo wenhua fazhan de tantao" (Examination of the evolution of Chinese culture in Taiwan over the last thirty years), in Chu Cen-lou (ed.), Wo guo shehui de bianqian yu fazhan (Social change and evolution in our country), Taipei, Sanmin shuju, 1981, pp. 103-177, and also pp. 118-120 and 137143

11. Chin Yao-chi (Ambrose King), Zhongguoren de san ge zhengzhi (Three political systems of the Chinese), Taipei, Jingji yu shenghuo chuban shiye gongsi, 1988, pp. 253-257; Zhongguo shehui yu wenhua (China: society and culture), Hong Kong, Oxford University Press, 1992.

12. Li Yih-yuan, Yang Kuo-shu, Zhongguoren de xingge (The character of the Chinese) Taipei, Guiguan tushu, 1988.

13. Yu Ying-shih, Lishi yu sixiang (History and thought), Taipei, Lianjing, 1976, particularly pp. 1-14.

14. Wang Qingjia (Edward Q. Wang), Taiwan shixue wushi nian (1950-2000), op. cit., p. 76

15. On the historical studies of Taiwan undertaken under the post-war Chinese Nationalist regime, cf. Ann Heylen, "From Local to National History: Forces in the Institutionalisation of a Taiwanese Historiography", China Perspectives, 37, September-October 2001: 39 51.

16. Allen Chun, "From Nationalism to Nationalizing: Cultural Imagination and State Formation in Postwar Taiwan," The Australian Journal of Chinese Affairs, 31, January 1994, pp. 49-69. 
continuity and the breaks between the island and the Chinese mainland. ${ }^{(17)}$

Chen Chi-nan's thought heralded the struggle, in the 1980s and 1990s, between Taiwan's opposition activists for recognition of a specifically Taiwanese history taking greater account of the plurality of historical experience on the island. Following in the footsteps of early supporters of independence who were forced to flee abroad after 1947, such as Ong Jok-tik (Wang Yu-teh) and Su Bing (Shih Ming), ${ }^{(18)}$ opponents of the Chinese Nationalist regime sought to reconnect with the historical roots of the people who inhabited Taiwan before the arrival of the Kuomintang. Reassessment of the aboriginal legacy of the island and of a specifically island history, stamped with a pioneer mindset and marked by a half-century of Japanese colonial presence that profoundly changed the socio-economic structure of the island, became from the 1980s onward a weapon in the struggle for the political emancipation of the Taiwanese from the Mainlanders. ${ }^{(19)}$ Through diverse concepts such as "ethnicity" (zuqunxing), "identity" (rentong), "collective memory" (jiti jiyl), "historical awareness" (lishi yishi), and "national imagination" (guojia xiangxiang), supporters of a new Taiwanese history, freed from the scheme of Chinese nationalist historiography, put forward a historical perspective centred on Taiwan and elaborated a new national narrative with nativist tendencies. ${ }^{(20)}$ However, those who challenged the instrumentalisation of Taiwanese history by the Kuomintang share some convergences with the official discourse from which they seek to distance themselves. In seeking to promote the idea of a Taiwanese specificity, Taiwan-centred historiography can sometimes display the same culturalist and essentialist shortcomings as its opposing nationalist Chinese historiography, which sought to promote Han cultural ascendancy and the "Sinity" of Taiwan in a homogenous and reductive manner.

Not until the 1990s, after the lifting of martial law, did the study of Taiwanese history acquire real institutional foundations and turn towards a more scientific approach. Nevertheless, the contributions of the extra-academic current represented by exiled supporters of independence and activists in the opposition to the Kuomintang were recognised over time by public opinion and by the institutions. Under their increasing influence, academic historians were in turn led to rethink the link between the Japanese colonisation and the formation of a modern Taiwanese identity, to rediscover the history of the aboriginal population and the Hakka migrants, their languages, and their cultures, and to re-examine the tragic events of 28 February $1947^{(21)}$ and the evolution of the
Taiwanese independence movement in Japan and in the United States, ${ }^{(22)}$ all of which were aspects and sequences of the history of the Taiwanese that Kuomintang propaganda had censored or consigned to oblivion.

\section{In search of a "scholarly native history": The critical thought of Chang Lung-chin}

Since they aspire to having their history recognised as a fully-fledged academic discipline, it is incumbent on Taiwanese historians to take into account its multiple origins and the diversity of the traditions and schools of knowledge of which it is constituted. Thus a new current, renowned in particular through the recent work of the historian Chang Lung-chih, calls for critical thought about the possibilities and conditions of elaboration of a "scholarly native history" (bentu xueshushi) endowed with its own analytical models, with an introspective reach on the ways of sounding out the tangle of continuities and upheavals in the historical development of the island. Chang Lung-chih asked the following question: "While at the turn of this century historical studies on Taiwan are clearly visible, does this mean that they have managed to establish themselves as a fullyfledged field of research, endowed with its own questions,

17. Chen Chi-nan's work on tuzhuhua, and that of Li Kwo-chi, on neidihua, were published for the first time in 1975. The following are later editions: Chen Chi-nan, Taiwan de chuantong Zhongguo shehui (Traditional Chinese society in Taiwan), Taipei, Yunchen chuban gongsi, 1987, particularly pp. 151-180; Li Kwo-chi, "Qingdai Taiwan shehui de zhuanxing" (Transformations of society in Taiwan under the Qing dynasty), Taipei, Jiaoyubu shehui jiaoyu si, 1978.

18. Ong Jok-tik (Wang Yu-teh), Taiwan. Kumen de lishi (Taiwan: A history full of bitterness), Taipei, Zili wanbao, 1993; Su Bing (Shih Ming), Taiwanren sibai nian shi (Four hundred years of history of the Taiwanese), Taipei, Caogen wenhua, 1998.

19. A-chin Hsiao, "Crafting a National History," in his book, Contemporary Taiwanese Cultural Nationalism, New York, Routledge, 2000, pp. 148-177.

20. Li Chiao, "Taiwan guojia de rentong jiegou" (Structures of National Identity in Taiwan), in Li Hung-hsi et al., Guojia rentong xueshu yantaohui lunwenji (Proceedings of the conference on national identity), Taipei, Xiandai xueshu yanjiu jijinhui, 1993, pp. 201-222. On the discourse on national identity in Taiwan and the 1990s and the readings of Taiwanese history it supports or allows, cf. Gunter Schubert, "A New Rising Nation? The Discourse on National Identity in Contemporary Taiwan," China Perspectives, 23, MayJune 1999, pp. 54-64.

21. These events, which left a deep scar in Taiwanese society, should be understood as resulting from the discontent of the island population with the Kuomintang, which, as soon as it arrived on the island in 1945, behaved like a coloniser, and against a background of galloping inflation sought to monopolise-among other things-the sale of alcohol and tobacco. On 28 February 1947, after a quarrel between a female cigarette-seller and some Kuomintang soldiers led to the death of a passerby, the island population, exasperated by the exactions and corruption of the Chinese Nationalist Party, rebelled. Historians estimate that the repression that followed resulted in 20,000 to 30,000 deaths among the islanders. Cf. Chang Yen-hsien, Li Wang-tai, and Yang Chen-lung, Er er ba shijian zeren guishu yanjiu baogao (Report to assign responsibility for the incidents of 28 February 1947), Taipei, Er er ba jijinhui, 2006.

22. On the Taiwanese independence movement cf. Chen Chia-hung, Taiwan duli yundong shi (History of the movement for the independence of Taiwan), Taipei, Yushanshe, 2006. 
its own methodological orientations and analytical models?" (23)

Chang Lung-chih takes as a starting point the "controversy over the modernisation of Taiwan" (Taiwan jindaihua lunzheng) between Kao I-ke and Tai Kuo-hui in 1983-1984. ${ }^{(24)}$ This controversy over the assessment of Japanese colonial heritage in Taiwan began in May 1983, when Yang $\mathrm{Pi}$ chuan, a former political prisoner and young activist in the opposition, published under the nom de plume of Kao I-ke an article in the journal Roots (Shenggen) entitled "Gotō Shimpei: Founding father of modernisation in Taiwan." By highlighting the successes achieved by the first Japanese Commissioner for Civil Affairs (who held the post on the island from 1898 to 1906), ${ }^{(25)}$ the writer aroused the anger of Chinese nationalist historians, who consider the time of the Japanese colonisation to be a dark age of oppression in Taiwan. In March 1984, the journal The China Current Forum (Xiachao luntan) published the proceedings of a conference in the United States where the historian Tai Kuo-hui violently attacked Yang Pi-chuan, accusing him of subservience to the Japanese colonial past and denouncing him for having a "colonised mentality" (beizhimin xintai). As Tai Kuo-hui saw it, the Manchu governor Liu Ming-chuan, mandated to the island between 1885 and 1891 , deserved credit for the first attempts to modernise Taiwan, ${ }^{(26)}$ which paved the way for Japan's policy of exploitation in its future colony.

According to Chang Lung-chih, while the controversy did not at the time give rise to a detailed critical examination of modern Taiwanese history or to analytical and interpretative models that would help to understand it, it nevertheless presents a twofold interest a posteriori, both historical and heuristic. Firstly, it sheds light on the intellectual and social context of Taiwan in the first half of the 1980s, dominated by the division of identity between promoters of "Taiwanese consciousness" (Taiwan yishi) and those of "Chinese consciousness" (Zhongguo yishi). ${ }^{(27)}$ Secondly, it raises the question of the possibility of a scholarly local history mindful of the criteria of its own periodisation, supposedly capable of shedding light on Taiwanese society's transition towards the modern era. Pursuing the debate of that time should make it possible to take soundings of the historical conditions that preceded modernisation of the island in the nineteenth and twentieth centuries, as well as examining the nature of the Manchu and Japanese administrations on the island, their similarities and differences, their interaction with native society, and their insertion into the process of state construction of the empires of which they were either an emanation or an extension. ${ }^{(28)}$
Chang Lung-chih therefore deems it important to explore the new "substitute" modes of historical narrative (tidaixing lishi xushi fangshi) capable of transcending the successive regimes in the history of Taiwan and of bringing out the economic and social evolutions over the longue durée. The idea underlying his work is that the condition of the tenant farmers and the lower orders of society, or the place and rights of women in Taiwan, among other examples, can be grasped as invariants, in the mathematical sense of the term, in the process of history. We must emphasise that it is not a case of fixing these states and dimensions of the social subject in an anhistoric immutability that would take no account of the willed nature of human action, of its ability to influence the course of events, and thus to produce its own evolutions. What is at stake is rather a reconsideration of these states and dimensions as data that do not concern any regime in particular, but include all the eras from the time that a socially organised and hierarchised human presence can be observed on the island. While political history has the virtue of bringing out the diversity of regimes in Taiwan, it tends to fragment the island's past by focusing narrative and analysis on political episodes conceived as breaks from one another. Chang Lung-chih's call for a reassessment of history over the longue durée from an economic and social angle echoes the methodological debate among the historians of the journal Thought and Language in the mid-1960s. It is therefore not new in the field of historical thought in Taiwan, except that this time he asks that the approaches adopted be applied to the case of Taiwan, as envisaged and considered for its own sake. In academic circles in the 1960s, still limited to the legacy of mainland intellectuals, attempts at applying a new historiography supported by the social sciences restricted themselves to the study of phenomena in China, and when they did not immediately eliminate the observation of local

23. Chang Lung-chih, "Zhimin xiandaixing fenxi yu Taiwan jindaishi yanjiu," op. cit., p. 134 24. Ibid., pp. 135-137.

25. For a critical analysis of Gotō Shinpei's policy in Taiwan, cf. Edward I. Chen, "Gotō Shinpei, Japan's Colonial Administrator in Taiwan: A Critical Reexamination," American Asian Review, 13.1, 1995, pp. 29-59.

26. On Governor Liu Ming-chuan's policy in Taiwan, cf. Samuel C. Chu, "Liu Ming-chuan and Modernization of Taiwan," The Journal of Asian Studies, 23.1, November 1963, pp. 3753.

27. On the division of identity between "Chinese consciousness" and "Taiwanese consciousness" at the end of the 1970s and during the decade of the 1980s in Taiwan, see Shih Min-hui (Chen Fang-ming), Taiwan yishi lunzhan xuanji (Collection of articles on the controversy over Taiwanese consciousness), Taipei, Qianwei chubanshe, 1989; and Hermann Halbeisen, "Taiwanese Consciousness (Tai-wan I Shih): Facets of a Continuing Debate," in E. Chen, J. Williams, J. Wong (ed.), Taiwan. Economy, Society and History, Hong Kong, 1991, pp. 235-250.

28. Chang Lung-chih, "Zhimin xiandaixing fenxi yu Taiwan jindaishi yanjiu," op. cit., pp. 135-137. 
realities in Taiwan, they did not seek to understand them for and in themselves. Later, in the 1970s, Li Kwo-chi's work on the neidihua and that of Chen Chi-nan on the tuzhuhua were motivated by a concern for a conceptualised analysis of island society in the Manchu period; in this, they remain pioneers. Nevertheless, they were unable to free themselves from the paradigm of a monographic local history, with no other objective at the time than to add to the knowledge of an undifferentiated whole, the Chinese world, perceived in a holistic way as well as generalised beyond the local. As we have seen, Li Kwo-chi's analysis focuses on the movement to integrate Taiwan with the Chinese mainland at the end of the nineteenth century. $\mathrm{He}$ seeks to demonstrate how the island aligned itself at the time on the model of a Chinese province, an evolution hastened by Western intrusion in the region, and whose path is the opposite of the efforts on the mainland, which at the same time was turning towards the West and borrowing its sciences and techniques. The explicitly stated objective of his study is not to shed light on a particular aspect, or to reconstitute a particular episode of the history of Taiwan, but to reassess the encounter between China and the West, emphasising the erratic and even contrary character of the process of modernisation that this confrontation precipitated from one place to another in the Chinese world. ${ }^{(29)}$ While Chen Chi-nan's study highlights certain endogenous factors of change in Taiwan during the Manchu period, it aims more generally to measure the evolutions specific to migrant Chinese societies originating from the regions of Southeast China, whom history chose to settle overseas. ${ }^{(30)}$

Chang Lung-chih therefore seeks to develop in Taiwanese historiography traditions of knowledge rooted in the native context and entirely dedicated to knowledge of it. He taxes recent work on the evolution of Taiwanese historiography, such as the book by Wang Qingjia (Edward Q. Wang), ${ }^{(31)}$ with referring excessively to the movement of Chinese historiography in Taiwan. Wang Qingjia's synthesis does tend to overestimate the influence of mainland intellectuals on the generation of researchers born on the island after the war. Moreover, the author underestimates the extra-academic movements that gave life in their own way to a memory and a history specific to Taiwan, and which interacted with the academic world in the wake of the democratic transition of the island's regime. ${ }^{(32)}$ Also somewhat undervalued is the decisive role of Japanese mediation in the elaboration of a Taiwanese historiographical tradition. ${ }^{(33)}$ Chang Lung-chih begins by enumerating works on the his- tory of Taiwan. Although these works are not always explicit on their methodological basis, they nevertheless illustrate the approaches he wants to reference as a starting point for a critical examination of the periodisation of the modern era in Taiwan. Chang draws up the following assessment: "Concerning the historiography of China, in which are confronted Chinese and Japanese theses and schools on questions such as the "transition from the Tang to the Song' or the existence of 'seeds of capitalism in the Ming-Qing era,' the historiography of Taiwan has not yet given rise to a comparison of viewpoints on the criteria of periodisation." (34)

The term "periodisation" is not to be understood here only in the sense of dating. This idea also implies a qualitative rather than a simply chronological historical demarcation. It is a question of seeing if, beyond the changes of political regime in Taiwan, one can distinguish in the history of the island a phase, an in-between, a turning-point, that would substantially affect the society, economy, and cultures of the island, and that would thus mark a period of transition of Taiwan towards the modern era. ${ }^{(35)}$ Chang Lung-chih encompasses a historical perspective in which the episode of the Japanese colonisation appears as an integral part of a modern age, of a temporality delineated as before or after the 1895-1945 period alone. ${ }^{(36)} \mathrm{Re}$ searchers into the history of Taiwan usually follow a rigid segmentation of political history without attempting to grasp the continuities and the upheavals that connect or section the various regimes, or to examine, from a comparative perspective and as "subjects of explanation" (jieshixing keti), relations between society and the state, interethnic connections, and the "reception of colonisations" on the island (zhimin jiechu). In this respect, Chang Lungchih points out, the work of the historian Wu Mi-cha, Studies on The Modern History of Taiwan, stands out as one

29. Li Kwo-chi, "Qingdai Taiwan shehui de zhuanxing," op. cit., pp. 1, 39-41.

30. Chen Chi-nan, Taiwan de chuantong Zhongguo shehui, op. cit., p. 155.

31. For the reference, cf. note 8 .

32. See Fiorella Allio, "Démocratisation et processus électoral à Taiwan," in M. DelmasMarty, P.-E. Will (dir.), La Chine et la démocratie, Paris, Fayard, 2007, pp. 735-802.

33. For a critical review of the work of Wang Qingjia, cf. Wang Jung-tsu, "Zhuixun ban shiji de zongji: ping Wang Qingjia Taiwan shixue wu shi nian," Taipei, Bulletin of the Institute of Modern History, Academia Sinica, 40, 2003, pp. 241-248.

34. Chang Lung-chih, "Zhimin xiandaixing fenxi yu Taiwan jindaishi yanjiu," op. cit., p. 137.

35. Ibid., pp. 137-138.

36. The American historian Harry Lamley emphasises the contribution of such a perspective to the elaboration, beginning in the 1970s, of a new Taiwanese history. Cf. Harry J. Lamley, "Taiwan Under Japanese Rule, 1895-1945: The Vicissitudes of Colonialism," in Murray A. Rubinstein (ed.), Taiwan: A New History, New York, M.E. Sharpe, Inc., 2007, pp. 201-260, and here, p. 202 [c1999]. 
of the rare books that raises openly, if only very briefly, the question of the criteria of periodisation of the history of Taiwan. ${ }^{(37)}$

Chang Lung-chih seeks to remove the 1983-1984 controversy on the modernisation of Taiwan from the sphere of mere ideology by showing that, beyond the political use that Tai Kuo-hui makes of his own work to counter his independence-supporting opponents, it is clear that he is concerned with highlighting socio-economic phenomena that, before and after the political upheaval of 1895 , corresponded with the Manchu period and the Japanese colonisation. In his study on the economy of the island at the end of the Qing dynasty, Tai Kuo-hui situates a little after the middle of the nineteenth century the emergence of merchant capitalism in Taiwan and the rapid growth of an independent merchant class represented by powerful guilds (hangjiao), around which was organised the network of imports and exports, and by the compradors (maiban) serving foreign companies after the opening of Taiwan to foreign trade in 1860 . The organisation of the production of sugar, camphor, and tea, the accumulation of capital (ziben leiji) resulting from the production and marketing of these commodities (chanxiao liucheng), as well as the interweaving of this circuit with the world market, appear as so many economic structures and conditions prior to, and necessary for, the development and rationalisation of capitalism in the future Japanese colony. ${ }^{(38)}$

According to Chang Lung-chih, the 1929 study by the Japanese economist Yanaihara Tadao, Taiwan Grapples with Imperialism, remains even today one of the most accomplished works, in terms of systematic analysis, on the beginning of the Japanese colonisation. ${ }^{(39)}$ One can nevertheless criticise the author for undervaluing, and even ignoring, certain specific and traditional forms of economic and social organisation in Taiwan prior to the Japanese occupation, with which the Japanese had to come to terms when they arrived on the island, and which necessarily gave a specific direction to the policy of colonial exploitation. This weakness in his work was noted in the mid-1970s by Tu Chao-yen, a Taiwanese economist trained at the University of Tokyo, who sought to correct it in a book, Taiwan in the Lap of Japanese Imperialism. ${ }^{(4)}$ In this work, Tu Chao-yen seeks to refocus on the native context by taking into account certain structures of Taiwanese society inherent in the traditional system of property-holding, the potentialities of which the Japanese cleverly grasped, and in the articulation of which they deployed their efforts at modernisation of the various sectors of activity on the island.
In both method and content, Tu Chao-yen's pioneering study in the elaboration of knowledge coincides with what Chang Lung-chih calls a posteriori "scholarly native history." However, it is probably in the work of the historian $\mathrm{Ka}$ Chih-ming, first published in English in 1987, that such knowledge most vigorously acquired renown. ${ }^{(4)}$ Following in the tradition of Tu Chao-yen, Ka Chih-ming examines to what extent a mode of social organisation specific to Taiwan, consubstantial with the clearing work and the system of land tenure prior to the Japanese colonisation, may have determined, favoured, or quite simply made effective the Japanese policy of colonial exploitation.

The approach favoured by Ka Chih-ming all through his work allows Chang Lung-chih to support his critical reflection on the historiography of Taiwan. ${ }^{(42)}$ It satisfies the theoretical criteria stipulated by the latter of a "scholarly native history" concerned with grasping the tangle of continuities and upheavals in the historical development of the island, and bringing out, in a comparative perspective and from an economic and social angle, the long-term trends in the island's history. $\mathrm{Ka}$ Chih-ming opts for a framework for understanding the facts in which the system of landholding itself is envisaged in the historical process as the "invariable" referred to above, which is to say a given in the organisation of human presence and activity that, while undergoing internal variations over time, has to be formally grasped in and through historiograpical observation over and above eras and political regimes.

Here we will examine Ka Chih-ming's work in more detail to better understand certain dynamics of the island's history and to see what reading of it he offers to grasp the transition of Taiwanese society towards the modern era. The next sec-

37. In his preface, the author justifies his decision to base his work on a chronological segmentation beginning in 1895. As he sees it, Japan's arrival in Taiwan had such repercussions on the historical consciousness of the population on the island that it constitutes a psychological threshold that founded the modern era. Cf. Wu Mi-cha, Taiwan jindaishi yanjiu (Studies on the modern history of Taiwan), Panchiao, Daoxiang chubanshe, 1991, pp. 1-3.

38. This study by Tai Kuo-hui, "Qing mo Taiwan de yi ge kaocha" (A storm over Taiwan at the end of the Qing dynasty), was first published in Japan. It is available in Chinese in a more recent Taiwanese edition published under the name of its author: Taiwan shi yanjiu. Huigu yu tansuo (Studies on the history of Taiwan: retrospective and exploration), Taipei, Yuanliu chuban gongsi, 1985, p. 27-88.

39. For a monograph in English on the life and work of Yanaihara Tadao, cf. Susan C. Townsend, Yanaihara Tadao and Japanese Colonial Policy: Redeeming Empire, Richmond, Curzon, 2000.

40. Cf. To Sh gen (Tu Chao-yen), Nihon teikokushugi-ka no Taiwan, Tokyo, Tokyo daigaku shuppan-kai, 1975

41. In this article we quote from the most recent edition of Ka Chih-ming's study: Japanese Colonialism in Taiwan: Land Tenure, Development, and Dependency, 1895-1945, Taipei, SMC Publishing Inc., 1996.

42. Cf. Chang Lung-chih, "Zhimin xiandaixing fenxi yu Taiwan jindaishi yanjiu," op. cit., p. 141 
tion will thus allow us to round off this article with a specific insight into a work that is highly representative of the new historiography of Taiwan elaborated over the past 20 years.

\section{Ka Chih-ming and the return to the land: Island society be- yond the political regimes}

\section{The land tenure system in the longue durée}

Ka Chih-ming dates back to the beginning of the Manchu period the genealogy of the structures that framed the property ownership system in Taiwan under the Japanese occupation. As we have noted, his approach comes within the scope of the longue durée. The question of land tenure constitutes the main thread for his sounding of the island society's past in a chronological framework that begins before the Manchu regime, at the time of the Dutch presence in Taiwan (1624-1662).

The first major clearing operations date back to this period, when the Dutch East India Company (VOC) brought peasants from the Chinese mainland to Taiwan a little before the middle of the seventeenth century. Previously, the island's territory had been inhabited by aboriginal peoples belonging to the linguistic group of Austronesian languages, who practised nomadic burning agriculture (growing millet, rice, yams, and taro), kept domestic animals (pigs, chickens, and dogs), and hunted (deer). The Chinese peasants recruited by the Dutch company were brought together in clearance groups under the authority of a local chief in the service of the Dutch. After the land had been exploited, they were assigned parcels of arable land, the size of which varied according to the work done in the clearance process, and in exchange for which they had to pay rent in kind to the Dutch company. Thus, owners were effectively tenant farmers. The land of Formosa was assigned to the explicit and exclusive ownership of the Dutch company, and the Chinese pioneers served it as tenants. Within the Royal domain no corvée was imposed on the peasants, but they had to pay a capitation tax, as well as numerous taxes in cash in order to practice certain activities (hunting, fishing, trade, or tree felling). ${ }^{(43)}$ Later, under the rule of the Cheng family (1662-1683), the war effort against the Manchus necessitated subsistence agriculture and an increase in grain reserves. Clearing work on the island intensified, but based on a new model: the agromilitary colony. In order to satisfy the food needs of the army, the garrison was assigned to the clearance and farm- ing of the land. From then on, the land-holding system revolved around a new typology of agricultural domains differentiated by status and mode of exploitation: public domain lands (guantian), garrison lands (yingpantian), and the fiefdoms of dignitaries (sitian). ${ }^{(4)}$

This system was elaborated at the time the Chengs took possession of Taiwan. They requisitioned the Dutch colonies on the island, which they placed under a central administration, and encouraged their dignitaries (for the most part military, but also civilian), as well as some local chiefs, to clear and exploit their own lands outside the public domain. This implied that they would acquire their own fiefdoms by impinging, willy-nilly, on the land inhabited by the aborigines. The system of military colonisation was an effective way to protect their lands, which were then exploited by soldier-tenants whose tasks varied according to their rank in the army. Garrison lands were exempt from taxes because they were called on to provide food for the troops, but the Cheng family's dignitaries had to pay the administration a land tax amounting to around a quarter of the produce raised on public domain lands. By paying a part of their harvest to the Chengs as tribute, the dignitaries assigned themselves the right to raise all sorts of taxes and to tax production within their fiefdoms. In time of war, however, they had to recruit soldiers among their tenants to serve in the fight against the Manchus. ${ }^{(45)}$

After taking Taiwan in 1683, the Manchus organised the transfer of land from the Chengs and their dignitaries to the tenants who had exploited it up to then, and who were now allowed to will their property to their descendants and to buy and sell land freely. Because the buying and selling of land was not subject to any legal restrictions under the Qing dynasty, Chinese families and influential merchants from the mainland, who were part of the civilian population, were able to take part in the clearance on the island and dominated all the activities of exploitation of the island's land.

One of the particularities of property ownership and land grants before the arrival of the Japanese lies in the phenomenon inherited from pioneer society, and well-known to Taiwanese historians and anthropologists, of dismemberment and superimposition of bare ownership and of usufruct

43. Cf. Chih-ming Ka, Japanese Colonialism in Taiwan, op. cit., pp. 11-13.

44. For a detailed analysis of the landholding system in Taiwan at the time of the Cheng, cf Tsao Yung-ho, "Zheng shi shidai zhi Taiwan ken zhi" (Clearance work in Taiwan at the time of the Cheng), in his book Taiwan zaoqi lishi yanjiu (Studies on the ancient history of Taiwan), Taipei, Lianjing chuban gongsi, 1981, pp. 255-294.

45. Chih-ming Ka, Japanese Colonialism in Taiwan, op. cit., p. 13 
within the system known as "large and small rent farming" (da xiao zu zhi). ${ }^{(46)}$ At the end of the eighteenth century there emerged in Taiwan a system of tenure at three levels, the genesis and workings of which have been described by $\mathrm{Ka}$ Chih-ming, and which issued from the large-scale clearance work begun on the island a century and a half before. In contrast with the property system on the Chinese mainland, where a class of vassal princes was under stricter control by the imperial authorities, the laxity of the Manchu administration in Taiwan favoured the emergence of a stratum of property entrepreneurs, designated in Chinese by the term kenhu, meaning literally "master clearer." Having obtained a "patent of reclamation" (kenzhao) accorded by the imperial authorities in exchange for the payment of an annual tax, the patent holders were authorised to undertake exploitation of the island's land. They did not carry out the work themselves, but recruited and supervised men who were charged with clearing the plots of land duly registered in the cadastre. Once the clearance work was completed, the kenhu retired, often far from their lands, most of them becoming city-dwellers, but continued to receive from their "perpetual tenants" (called dianhu or yongdianhu) rent in kind defined in the framework of a tenancy contract called a "charter of usufruct" (jidianpi). ${ }^{(47)}$ Over the course of the seventeenth century, the figure of the kenhu, originally very influential because of their rank and function in pioneer society, began to fade in favour of the perpetual tenants, whose usufruct of the land developed into a right of quasiownership. Practice at the end of the eighteenth century shows that perpetual tenants who paid their rent to a major owner escaped his control entirely. Thus, at the turn of the nineteenth century, the perpetual tenants in their turn, and without the agreement of the kenhu, granted the usufruct of part of their land to peasant tenant farmers (xiangeng dianhu), a sort of sub-tenant, demanding also from them the payment of rent based on a share-cropping lease. ${ }^{(48)}$ To distinguish the rent received by the kenhu from that received from the dianhu, Taiwanese historians, who refer to customary law, refer to the first type as "large rent" (dazu) and the second as "small rent" (xiaozu). ${ }^{(49)}$

\section{Widening the perspective by means of comparison}

Comparative perspective, referred to by Chang Lung-chih, is a constant in the work of $\mathrm{Ka}$ Chih-ming; it seeks to grasp as closely as possible the native Taiwanese context in its singularity. Thus Ka mentions the work published in the 1950s by the Japanese scholars Okuda Iku and Higashi Yashio, whom he sees as having sought to establish in an oversimplified way a parallel between the landholding system in the Dutch period in Taiwan and the seigneurial regime that emerged in Europe in the thirteenth century. As he sees it, the Dutch colonial enterprise in Formosa contrasts strongly with the European case in being motivated by trade and profit rather than by a desire to set up a seigneurial economy that would be self-sufficient on the scale of the island. The land-holding and tenancy system introduced by the Dutch aimed at increasing the production and shipping of the island's raw materials (mainly sugar) with a view to their export on the world market. ${ }^{(50)}$

$\mathrm{Ka}$ Chih-ming also cast an eye on the landholding system on the Chinese mainland in the province of Fujian. While the terminology used in customary law in Taiwan comes from the coastal region of Zhangzhou, the two realities to which it applies are highly differentiated between the two places. $\mathrm{Ka}$ Chih-ming criticises the works of Edgar Wickberg and Ronald Knapp ${ }^{(51)}$ for amalgamating the landholding in Formosa with that in South China beginning with the Ming dynasty, a system referred to as "one domain, two masters" (yi tian liang zhu). According to Ka Chih-ming, Wickberg and Knapp did not understand that the dazu/xiaozu distinction in Fujian referred to a differentiation among landowners, while in Taiwan it was used to distinguish the tenants from their subtenants. ${ }^{(52)}$

\section{The nature of the outside powers and their interaction with native society}

Ka Chih-ming's study also allows us to consider the nature of the regimes on the island and their interaction with native

46. For works in English on the property system in Taiwan, cf. Edgar Wickberg, "Continuities in Land Tenure, 1900-1940," in E. Ahern, H. Gates (eds.), The Anthropology of Taiwanese Society, Stanford (California), Stanford University Press, 1981, pp. 212-240; Ronald G. Knapp, "Settlement and Frontier Land Tenure," in R. G. Knapp (eds.), China's Island Frontier, Taipei, SMC Publishing Inc., 1995, pp. 55-68; and John Shepherd, Statecraft and Political Economy on the Taiwan Frontier, 1600-1800, Taipei, SMC Publishing Inc., 1995.

47. Chih-ming Ka, Japanese Colonialism in Taiwan, op. cit., pp. 11-21.

48. Ibid., pp. 21-27.

49. The term "large rent" does not mean that the corresponding rent was higher than that of the so-called "small rent." On the contrary, perpetual tenants received from their subtenants a rent in kind equivalent to a proportion of the crop much higher than what they themselves had to pay to their landowners. The lands sublet to the peasant tenants were all the more valuable for being already ready for farming, and thus produced stable returns. In 1830, the amount of minor tenancy was on average four times that of the major tenancy. See Chih-ming Ka, Japanese Colonialism in Taiwan, op. cit., pp. 19, 24.

50. Ibid., p. 12.

51. For the references to the work of Wickberg and Knapp, cf. note 47.

52. Chih-ming Ka, Japanese Colonialism in Taiwan, op. cit., pp. 24-27. 
society. It first reveals the extremely lax character of the control exercised by the Manchu authorities in Taiwan, which was based on the form of organisation structured on the kenhu/dianhu combination. The political logic of the formation of the social stratum of the kenhu centres on the role they played during the great clearance works in keeping order on the frontier lands and collecting taxes in areas where the imperial administration was very thin on the ground or ineffective. It was in exchange for the work done by the land entrepreneurs in guaranteeing security and establishing taxation on the island that the Manchu court granted them legal title of ownership of the land, and the right to recruit their own tenants and receive rent from them.

At the end of the nineteenth century, under increasing threat from the European and Japanese imperial powers, the Manchu court became aware of the importance of the geostrategic position of Taiwan in the defence of the Empire. The policy of compromise with an undisciplined island society was no longer acceptable. The imperial authorities tried to supplant the socio-political function of the local chiefs and major absentee landowners by reinforcing the central state on the island. However, the reform implemented by the governor Liu Ming-chuan to increase state receipts by directly taxing farmers and effectively recognising them as the only legal owners of the land came up against the combined resistance of the tenants and landowners. ${ }^{(33)}$

When they arrived in Taiwan, the Japanese succeeded where the Manchu administration had failed in putting in place a coercive system of management. The isolation of the island's population, and the strength of the ties of obligation and dependence between landowner and tenant on which the entire Manchu system rested, had constantly hampered the control of central government. The Japanese did not attempt to eradicate this form of local joint management, which they saw could be diverted to the benefit of government centralisation and would help them establish their hegemony over the island by neutralising the opposition as inexpensively as possible. There was no need to replace the Manchu system with a new and totally foreign form of organisation. It was enough simply to lean on the existing system and give it full political and economic effectiveness by increasing the centralisation of the colonial administration. ${ }^{(54)}$ In 1898 , the Japanese military authorities established a rigorous administrative grid, adapting to their own use the traditional baojia system of mutual surveillance and responsibility among village communities, the workings of which they managed to rationalise and make into a powerful auxiliary police force. ${ }^{(55)}$ This supervision down to the smallest local level allowed the drawing up of a very precise assessment of the farming system and the taking of accurate soundings of the social structure. ${ }^{(56)}$ Between 1898 and 1903, the Japanese used the tight mesh of the baojia system to undertake rigorous cadastral research in order to register the land of the owners, whose productive value they estimated by determining the cost of the rents, the kinds of cultivation, and the size of the crops. Very quickly, they noticed that the undeclared lands on the island were equivalent to no less than half of the area of land being taxed, which amounted to a considerable source of potential revenue for a government financing a costly colonial enterprise. However, in order to increase public revenues, they had to simplify the traditional landholding system, the extreme complexity of which hampered the development of agriculture and the increase of taxes. Agrarian reform was one of the pillars of the Japanese policy of exploitation. The colonial authorities realised that the major landowners had been on the decline for a long time, and that governor Liu Ming-chuan's reforms had only weakened them further. They took advantage of this trend to set up a simple and uniform system of tenure based on freehold ownership under which the colonial authorities bought out the rights of the major land entrepreneurs and made their perpetual tenants the effective owners of the domains they had farmed up to then. At the same time, they facilitated the calculation of taxes by land area rather than productivity. Now responsible for paying tax, and in some cases entrusted with the administration of village communities, the new landowners were placed directly within the power of the government, which matched the cadastre with the tax to avoid any fiscal leakage. The landholding reform made it possible to maintain a high concentration of land ownership in the hands of its new possessors, but by considerably reducing their expenses and diverting the income from the land to them, it encouraged them to be more productive. It was by maintaining the structure of rural society and traditional social relations in Taiwan that the Japanese were able to efficiently develop the island's agriculture, in particular the production of rice and sugar cane. ${ }^{(57)}$

53. Ibid., pp. 33-35.

54. Catherine Paix, Michèle Petit, "Un passé colonial et sa réinterprétation: la spécificité de la colonisation japonaise à Taiwan," Strates. Matériaux pour la recherche en sciences sociales, 1987, pp. 81-115, in particular p. 86.

55. On the origins of the baojia system in China, its adaptation and evolution in Taiwan during the Japanese colonisation, cf. Chen Ching-chih, "The Japanese Adaptation of the Pao-Chia System in Taiwan, 1895-1945," The Journal of Asian Studies, 34.2, February 1975, pp. 391-416.

56. Catherine Paix, Michèle Petit, “Un passé colonial et sa réinterprétation,” op. cit., pp. 86-87.

57. Chih-ming Ka, Japanese Colonialism in Taiwan, op. cit., pp. 58-62. 
As Ka Chih-ming puts it, his analysis shows that "the formation of Taiwan's family farming agriculture based on modern ownership during the colonial period was not a simple process of dissolution of the indigenous system and assimilation of an exogenous one. Rather than implanting a modern system from Japan, the colonizer fostered a land tenure system approximating modern free absolute ownership by modifying and further developing the existing tendencies embedded in Taiwan's tenurial system, namely, the rise of perpetual tenants' land rights and the decline of the patent holders." (58)

As Ka Chih-ming sees it, the changes in the system of tenure in Taiwan were structured in a subtle dialogue of mutual accommodation between the outside powers and native society. This interaction expresses a multiple temporality, that of the colonial moment in a given endogenous configuration. He bases himself on a long periodisation of the history of the island that goes beyond political segmentation to take into account processes affecting the substance of native society. He offers a gradual reading of the arrival on the island of a new form of social organisation: the free and direct management of land by small owner-operators. Against the background of the decline of the social function of the major absentee landowners and the rise in tenants' rights can be seen the birth of modern land ownership. Thus, even if they did not initiate a period defined as modern, the Japanese authorities clearly perceived the traits of the existing system, its potential, and its internal propensities. Their acuity lies in having compromised with the changes that had begun to appear in the traditional landholding system, which in turn facilitated the policy of exploitation of the colony. The establishment of the Japanese regime, which brought an end to the Chinese colonisation under Manchu imperial authority, is certainly a political disjunction. But because the Japanese administration closely followed the developments in native society, its ability to accelerate and give direction to the process and progress makes it party to the extension of a continuous historical movement that can be illuminated by an analysis of land tenure and ownership.

\section{conclusion}

The theoretical reflection of Chang Lung-chih and the work of $\mathrm{Ka}$ Chih-ming are excellent illustrations of the richness of the historiographical debate in Taiwan over the last 20 years. Both are part of an effort of modelisation of Taiwanese historiography in that they seek to provide it with its own methodologically situated analytical models, which facil- itate a grasp of the island's past and the context native to Taiwan over the longue durée. Other historians are also actively engaged in this. After the changeover of political power between parties in 2000, which marked the arrival in government of the Progressive Democrats, the work of modelisation benefited from institutional support that further enhanced its chances of flourishing. A new generation of researchers at the Institute of the History of Taiwan at the Academia Sinica, which was officially inaugurated in 2004 after 10 years of preparation, has worked towards diversification of the thematics and points of view in historical studies on Taiwan. Taiwanese historians are now focusing on the history of ideas, techniques, colonial elites, the masses, women, traders, etc. A book by Chen Jou-chin published in 2005, for example, offers an analysis that combines the history of mentalités with the history of material culture in Taiwan. ${ }^{(59)}$

Since 2000 the sociologist Hsiau A-chin has been analysing the strategic, political, and ideological stakes underlying the re-reading of the history of Taiwan by activists in the political opposition beginning in the 1970s. His recent book Return to Reality bears the mark of various trends in Western social sciences, which from Karl Mannheim to Lewis and Sandra Hinchman, as well as Maines, Somers, and Gibson, have sought to redefine the notions of identity, social action, and collective memory in their narrative dimension. Reference to the philosophy of Paul Ricœur is also present in the work of Hsiau A-chin, who emphasises the structural relationship between history and fictional narrative. ${ }^{(60)}$

The postcolonial approach has also made it possible for Taiwanese historians to dissect the mechanisms of domination and the representations of constructed otherness appearing in colonial rhetoric. Works in English by Emma Jinhua Teng, Faye Yuan Kleeman, and Robert Eskildsen that have attracted academic attention to Taiwan in the last few years show that during the Manchu period as well as during the Japanese period, literary, historical, and geographical works that were supposed to be factually informative were steeped in idealised and stereotyped representations of the island and its first inhabitants, and contained reductive prejudices and fantasies. These representations recur from one period to another, even though the framework of domination

\footnotetext{
58. Ibid., p. 39
}

59. Chen Jou-chin, Taiwan xifang wenming chutiyan (The first experiences of [modern] Western civilisation in Taiwan) Taipei, Maitian chubanshe, 2005.

60. Hsiau A-chin, Huigui xianshi: Taiwan yi jiu qi ling niandai de zhanhou shidai yu wenhua zhengzhi bianqian (Return to reality: The postwar generation and the cultural and political changes in Taiwan in the 1970s), Taipei, Zhongyanyuan shehuisuo, 2008. 
changed and research definitively turned towards empirical knowledge. ${ }^{\left({ }^{(1)}\right.}$

Finally, Taiwanese historians increasingly favour a world and transnational approach on the one hand, and a regional dialogue with East and Southeast Asia on the other. This trend, which is asserting itself, for example, in the collective work published under the direction of $\mathrm{Wu}$ Mi-cha and Masahira Wakabayashi, ${ }^{\left({ }^{(2)}\right)}$ shows that the modelisation of the historiography of Taiwan now demands a broader view and a change in contextual scale aimed at better grasping the globalised connections of interaction and interdependence at the intersection of which Taiwan was located from the six- teenth century onwards. The historical experiences and cultural influences on the island (Austronesian, Chinese, Dutch, Spanish, Japanese, and American) that Taiwanese historians seek to re-examine with their foreign colleagues bear witness to a plurality of temporalities and historicities. At the intersection of the local and the global, of the micro and the macro, they appear as so many exogenous contributions in colonial situations, while simultaneously specific endogenous factors of development have contributed over time to the emergence of a singular historical-cultural mosaic that moulds and acts as the basis of Taiwanese belonging in the present. $\bullet$

61. Emma Jinhua Teng, Taiwan's Imagined Geography: Chinese Colonial Travel Writing and Pictures, 1683-1895, Cambridge (Massachusetts), Harvard University Press, 2004; Faye Yuan Kleeman, "Gender, Ethnography, and Colonial Cultural Production," in Liao Pinghui, David Der-wei Wang (eds.), Taiwan Under Japanese Colonial Rule, 1895-1945: History, Culture, Memory, New York, Columbia University Press, 2006, pp. 294-311; Robert Eskildsen, "Of Civilization and Savages: The Mimetic Imperialism of Japan's 1874 Expedition to Taiwan," American Historical Review, 107.2, April 2002, pp. 388418.

62. For the references of this book, cf. note 2 . 


\section{Glossary}

baojia 保甲

beizhimin xintai 被殖民心態

bentu xueshushi 本土學術史

chanxiao liucheng 產銷流程

da xiao zu zhi 大小租制

dazu 大租

dazuhu 大租户

dianhu 佃户

fandi 番地

guantian 官田

guojia xiangxiang 國家想象

guojia xingge 國家性格

guoshi 國史

hangjiao 行郊

jidianpi 給佃批

jieshixing keti 解釋性課題

jiti jiyi 集體記憶

kaozheng 考證學

kenhu 鲘户

kenzhao 墾照

lishi yishi 歷史意識

maiban 買辦

neidihua 內地化

rentong 認同

shehui xingwei 社會行爲

shiliao xuepai 史料學派

shinkokugaku 新國學

sitian 私田

Taiwan jindaihua lunzheng 薹灣近代化論爭

Taiwan yishi 臺灣意識

teikoku nanshin 帝國南進

tidaixing lishi xushi fangshi 替代性歷史敍事方式

tuzhuhua 土著化

xiangeng dianhu 現耕佃户

xiaozu 小租

xiaozuhu 小租户

yi tian liang zhu 一田兩主

yingpantian 營盤田

yongdianhu 永佃户

zhimin jiechu 殖民接觸

Zhongguo yishi 中國意識

ziben leiji 資本累積

zuguo 祖國

zuqunxing 族群性
Academia Sinica 中央研究院

Ambrose King (Chin Yao-chi) 金燿基

Chang Lung-chih 張隆志

Chen Chi-nan 陳其南

Chen Jou-chin 陳柔緹

Fu Ssu-nien 傅斯年

Fujita Toyohashi 藤田豐八

Fukuzawa Yukichi 福澤諭吉

Gotō Shinpei 後籐新平

Higashi Yashio 東嘉生

Hsiau A-chin 蕭阿勤

$\mathrm{Hu}$ Shih 胡適

Ichimura Sanjirō 市村垸次郎

Iwao Seiichi 岩生成一

Ka Chih-ming 柯志明

Kao I-ke 高伊哥

Kawano Shigetō 川野重任

Kuwabara Jitsuzō 桑原隲藏

Li Kwo-chi 李國祁

Li Yih-yuan 李亦園

lishi yuyan yanjiusuo 歷史語言研究所

Liu Ming-chuan 劉銘傳

Wakabayashi Masahiro 若林正丈

Murakami Naojirō 村上直次郎

Naka Michiyo 那珂通世

Okuda Iku 奥田或

Ong Iok-tek (Wang Yu-teh) 王育德

Shenggen 生根

Shigeno Yasutsugu 重野安繹

Shihuo yuekan 食貨月刊

Si yu yan 思與言

Su Bing (Shih Ming) 史明

Tai Kuo-hui 戴國煇

Taihoku teikoku daigaku 台北帝國大學

Tu Chao-yen 涂照彥

Wang Qingjia (Edward Q. Wang) 王晴佳

Wu Mi-cha 吴密察

Xiachao luntan 夏潮論壇

Yanaihara Tadao 矢內原忠雄

Yang Kuo-shu 楊國樞

Yang Pi-chuan 楊碧川

Ye Chi-cheng 葉啓政

Yu Ying-shih 余英時 